\title{
Activation of Phosphatidylinositol-3 Kinase by Nerve Growth Factor Involves Indirect Coupling of the trk Proto-Oncogene with src Homology 2 Domains
}

\author{
Masahide Ohmichi, ${ }^{*+}$ Stuart J. Decker, ${ }^{+\neq}$ \\ and Alan R. Saltiel*t \\ *Department of Physiology \\ ₹Department of Microbiology \\ University of Michigan School of Medicine \\ Ann Arbor, Michigan 48109 \\ tDepartment of Signal Transduction \\ Parke-Davis Pharmaceutical Research Division \\ Warner-Lambert Company \\ Ann Arbor, Michigan 48105
}

\section{Summary}

Growth factor receptor tyrosine kinases can form stable associations with intracellular proteins that contain src homology (SH) 2 domains, including the p85 regulatory subunit of phosphatidylinositol (PI)-3 kinase. The activation of this enzyme by growth factors is evaluated in PC12 pheochromocytoma cells and NIH 3 T3 fibroblasts expressing the pp140 ${ }^{\text {ctrk }}$ nerve growth factor (NGF) receptor (3T3-c-trk). NGF causes the rapid stimulation of Pl-3 kinase activity detected in anti-phosphotyrosine, but not in anti-trk, immunoprecipitates. This effect coincides with the tyrosine phosphorylation of two proteins, with molecular masses of of $100 \mathrm{kd}$ and $110 \mathrm{kd}$, that coimmunoprecipitate with p85. Similar phosphorylation patterns are induced when an immobilized fusion protein containing the amino-terminal $\mathrm{SH} 2$ domain of p85 is used to precipitate tyrosine-phosphorylated proteins. Thus, although NGF produces the rapid activation of PI-3 kinase through a mechanism that involves tyrosine phosphorylation, there is no evidence for tyrosine phosphorylation of p85, or for its ligand-dependent association with the NGF receptor. Perhaps another phosphoprotein may link the NGF receptor to this enzyme.

\section{Introduction}

Although the mechanisms by which neurotrophins such as nerve growth factor (NGF) support the survival and differentiation of sympathetic and sensory neurons remain elusive, it is recognized that early changes in protein phosphorylation ultimately play an important role in the cellular actions of the growth factor. NGF increases the phosphorylation of several cellular proteins (Halegoua and Patrick, 1980; Nakanishi and Guroff, 1985; Landreth and Rieser, 1985) and is known to stimulate the activities of several serine/ threonine kinases (Lee et al., 1985; Hama et al., 1986; Matsuda and Guroff, 1987; Rawland et al., 1987; Aletta et al., 1988; Heasley and Johnson, 1989a, 1989b; Vulliet et al., 1989; Miyasaka et al., 1990; Ohmichi et al., 1992b). Recent evidence (Kaplan et al., 1991a; Klein et al., 1991; Weskamp and Reichardt, 1991; Ohmichi et al., 1992b) indicates that these serine/threonine phosphorylations result from the direct binding of NGF to its high affinity receptor, pp140 ${ }^{\text {trk. }}$. This receptor is a protein tyrosine kinase, and both its activity and tyrosine autophosphorylation are increased in response to NGF (Kaplan et al., 1991b; Ohmichi et al., 1991b).

The precise tyrosine phosphorylation substrates that initiate the differentiative responses of neurons to neurotrophins have yet to be identified. However, the many similarities in eary phosphorylation events produced by differentiative agents like NGF and mitogenic agents like epidermal growth factor (EGF) suggest that subtle differences in signaling events are required to distinguish different cellular fates. One mechanism for the divergence in signals initiated by tyrosine kinase receptors may be their differential interactions with effector proteins containing src homology $2(\mathrm{SH} 2)$ domains. Three such signaling proteins, phospholipase C (PLC)- $\gamma 1$ (Wahl et al., 1988; Margolis et al., 1989; Meisenhelder et al., 1989; Wahl et al., 1989a, 1989b), GTPase activating protein of ras (Molly et al., 1988; Trahey et al., 1988; Ellis et al., 1990), and phosphatidylinositol (PI)-3 kinase (Bjorge et al., 1990), are phosphorylated on tyrosine residues in response to numerous growth factors and can form stable associations with receptors in a growth factordependent manner (Kumjian et al., 1989; Kaplan et al., 1990; Kazlauskas et al., 1990; Margolis et al., 1990a; Cantley et al., 1991; Hu et al., 1992) via an interaction with the SH2 domain (Coughlin et al., 1989; Anderson et al., 1990; Margolis et al., 1990b; Moran et al., 1990; Escobedo et al., 1991a, 1991b; Otsu et al., 1991; Skolnik et al., 1991). We recently reported that NGF stimulates the association of its high affinity $\mathrm{pp} 140^{\text {r-trk }}$ receptor with the $\mathrm{SH} 2$ domains of PLC- $\gamma 1$ in PC12 pheochromocytoma cells (Ohmichi et al., 1991b) and further that the constitutively active $\mathrm{p} 70^{\text {cttrk }}$ oncogene product is also associated with $\mathrm{PLC}-\gamma 1$ through its $\mathrm{SH} 2$ domains (Ohmichi et al., 1991a). Moreover, the NGF-dependent association of $\mathrm{pp} 140^{\mathrm{c}-\mathrm{trk}}$ with PLC- $\gamma 1$ correlates with the tyrosine phosphorylation of a $38 \mathrm{kd}$ phosphoprotein, which itself coprecipitates with both pp140-trk and the $\mathrm{SH} 2$ domains of PLC- $\gamma 1$ in response to NGF (Ohmichi et al., 1992c).

Although there was no detectable association of the NGF receptor with GTPase activating protein of ras (Ohmichi et al., 1991b), preliminary results indicated that NGF stimulated the phosphorylation of two proteins that specifically bound to the p85 subunit of PI-3 kinase (Ohmichi et al., 1992c). This enzyme phosphorylates $\mathrm{PI}$ on the D3 position of the inositol ring, leading to the formation of the novel phosphoinositides $\mathrm{Pl}-3 \mathrm{P}, \mathrm{PI}-3,4 \mathrm{P}_{2}$, and $\mathrm{PI}-3,4,5 \mathrm{P}_{3}$. Although the precise functions of these lipids remain unknown, the exposure of cells to growth factors (Kaplan et al., 1987; Whitman et al., 1987; Auger et al., 1989) or oncogenic transformation (Fukui et al., 1991) causes their accumulation. Moreover, mutational analyses of the platelet-derived growth factor (PDGF) (Coughlin et al., 

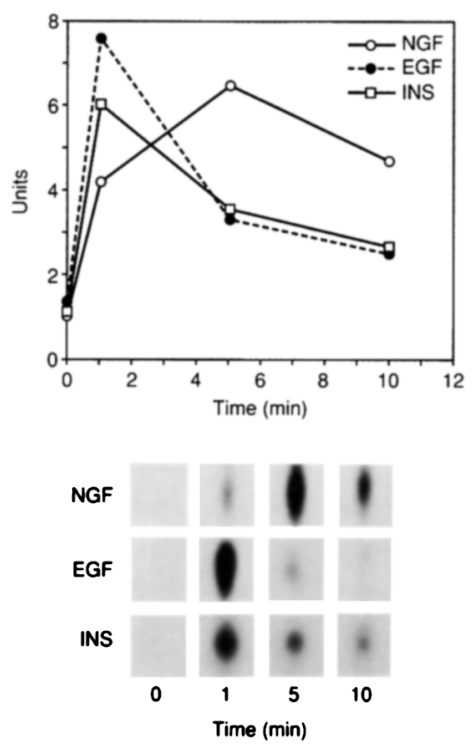

Figure 1. NGF, EGF, and Insulin Stimulate PI-3 Kinase Activity in Anti-Phosphotyrosine Immunoprecipitates of PC12 Cells PC12 cells were grown in $150 \mathrm{~mm}$ dishes. NGF (100 nM), EGF (10 rM), or insulin (100 ruM) was directly added to the medium and incubated for the indicated times at $37^{\circ} \mathrm{C}$. Lysates were immunoprecipitated with anti-phosphotyrosine antiserum, and PI-3 kinase activity was measured by incubating with $\left[\gamma_{-32}{ }^{32}\right]$ ATP and PI as described in Experimental Procedures. One unit of activity is defined as nmoles of PI-3P per $\min \left(\times 10^{-2}\right)$. In the lower panel are shown autoradiographs of the region of the thin-layer chromatograph containing PI-3P. Results are from a single experiment that was repeated three times.

1989), EGF (Bjorge et al., 1990), and colony stimulating factor (Varticovski et al., 1989; Reedijk et al., 1990; Shurtleff et al., 1990) receptors indicated a strong correlation between stimulation of cell growth and $\mathrm{PI}-3$ kinase activation. Since NGF, EGF, and insulin paradoxically share a number of common early signaling pathways (Saltiel and Decker, 1991), we have compared the actions of these three growth factors on stimulation of $\mathrm{Pl}-3$ kinase activity and association of tyrosine-phosphorylated proteins with its $85 \mathrm{kd}$ regulatory protein. These results indicate that the high affinity NGF receptor differentially associates with $\mathrm{SH}$-containing proteins, via direct or indirect mechanisms.

\section{Results}

\section{NGF Stimulates PI-3 Kinase Activity}

Via Its pp $140^{\text {ctrk }}$ Receptor

NGF binding to the pp140 $10^{\text {ctrk }}$ receptor stimulates its association with the $\mathrm{SH} 2$ domains of $\mathrm{PLC}-\gamma 1$ in both PC12 (Ohmichi et al., 1991b) and 3T3 fibroblasts expressing the human pp140 c-trk (3T3-c-trk) (Ohmichi et al., 1992c) as well as its phosphorylation on tyrosine (Kim et al., 1991; Ohmichi et al., 1991b). To explore the involvement of other $\mathrm{SH} 2$ proteins in NGF action, we assayed the activity of $\mathrm{PI}-3$ kinase in these cells after
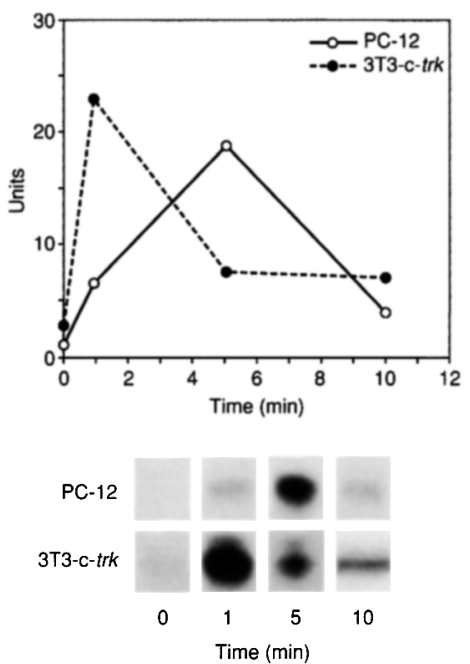

Figure 2. NGF Stimulates PI-3 Kinase Activity in Anti-phosphotyrosine Immunoprecipitates of PC12 and 3T3-c-trk Cells

PC12 and 3T3-c-trk cells were grown in $150 \mathrm{~mm}$ dishes. NGF (100 $\mathrm{nM}$ ) was directly added to the medium and incubated for the indicated times at $37^{\circ} \mathrm{C}$. Lysates were immunoprecipitated with anti-phosphotyrosine antiserum, and PI-3 kinase activity was measured as described in Figure 1. Autoradiographs are shown in a lower panel.

exposure to NGF, EGF, and insulin. Following hormonal treatment, lysates were precipitated with antiphosphotyrosine antiserum, and the resulting immunoprecipitates were assayed for phosphorylation of PI (Figure 1). In PC12 cells, NGF rapidly activated PI-3 kinase activity that was detected in anti-phosphotyrosine immunoprecipitates. This effect was observed after $1 \mathrm{~min}$ of exposure and was maximal at $5 \mathrm{~min}$, but declined thereafter. Similarly, both EGF and insulin also stimulated the activity of this enzyme in antiphosphotyrosine immunoprecipitates. Effects of these hormones were maximal after only $1 \mathrm{~min}$ of exposure and declined thereafter.

The NGF-dependent activation of PI-3 kinase was also explored in $3 T 3$ cells that were transfected with the pp140 14 -trk cDNA. These cells express the $140 \mathrm{kd}$ high affinity receptor, but contain no low affinity $p 75$ receptor (Ohmichi et al., 1992b). Exposure of 3T3-c-trk cells to NGF also caused an increase in PI-3 kinase activity, although the time course was slightly faster than that observed in PC12 cells, occurring maximally at $1 \mathrm{~min}$ (Figure 2). These data provide further evidence that the pp $140^{\text {ctrk }}$ receptor is both necessary and sufficient for the early signaling events in NGF action.

To explore further the mechanism of activation of PI-3 kinase in response to NGF, PC12 or 3T3-c-trk cells were treated with NGF and subsequently immunoprecipitated with anti-phosphotyrosine, anti-trk, or antisera raised against the $85 \mathrm{kd}$ regulatory subunit of $\mathrm{PI}-3$ kinase prior to assay of PI-3 kinase activity (Figure 3 ). Although NGF produced a marked increase in PI-3 kinase activity detected in anti-phosphotyrosine im- 

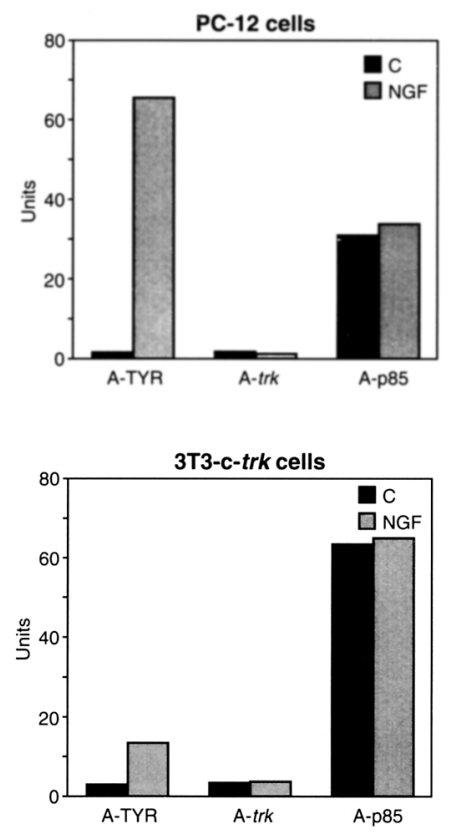

Figure 3. NGF-Stimulated PI-3 Kinase Activity Is Not Detected in Anti-trk or Anti-p85 Immunoprecipitates from PC12 or 3T3-c-trk Cells

PC12 and 3T3-c-trk cells were grown in $150 \mathrm{~mm}$ dishes. NGF (100 $\mathrm{nM}$ ) was directly added to the medium and incubated for $5 \mathrm{~min}$ in PC12 cells or $1 \mathrm{~min}$ in $373-\mathrm{c}$-trk cells at $37^{\circ} \mathrm{C}$. Lysates were immunoprecipitated with an li-phos photyrosine, anti-trk, or antip85 antisera, and PI-3 kinase activity was measured as described in Figure 1.

munoprecipitates from both cell types, no significant increase was observed in anti-trk immunoprecipitates. In addition, precipitation with a glutathione S-transferase (GST) fusion protein containing the $\mathrm{SH} 2$ domain of p85 also brought down NGF-stimulated PI-3 kinase activity (data not shown). Immunoprecipitation with anti-p85 antisera brought down significant enzyme activity in the absence of NGF; however, there was no significant increase upon NGF treatment. The elevated activity observed in these immunoprecipitates may reflect activation of the enzyme by antibody binding to the 855 subunit, mimicking the activation produced by binding of tyrosine-phosphorylated proteins to the $\mathrm{p} 85 \mathrm{SH} 2$ domain.

\section{NGF Stimulates the Association of Tyrosine-Phosphorylated Proteins with the 85 kd Subunit of PI-3 Kinase}

Recent studies indicate that binding of certain growth factors to their receptors can induce a stable association with p85 of PI-3 kinase (Kaplan et al., 1987; Escobedo et al., 1991a) as well as the phosphorylation of this protein (Kazlauskas and Cooper, 1989, 1990). To determine whether the activation of PI-3 kinase by NGF occurs through a similar mechanism, PC12 cells were treated with NGF, EGF, or insulin, and lysates were precipitated with anti-p85 antiserum (Figure 4). The resulting immunoprecipitates were electropho-

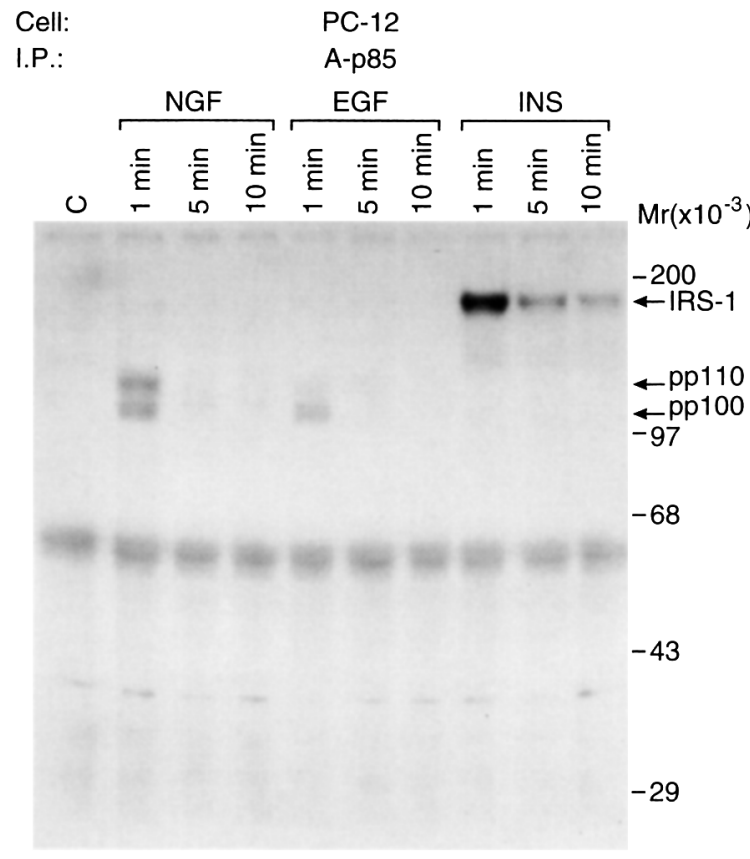

Figure 4. NGF, EGF, and Insulin Stimulate the Tyrosine Phosphorylation of Proteins in PC12 Cells That Coprecipitate with p85 PC12 cells were grown in $150 \mathrm{~mm}$ dishes. NGF (100 nM), EGF (10 $\mathrm{nM})$, or insulin $(100 \mathrm{nM})$ was directly added to the medium and incubated for the indicated times at $37^{\circ} \mathrm{C}$. Lysates were immunoprecipitated with anti-p85 antiserum and subject to SDS-PAGE, followed by immunoblotting with anti-phosphotyrosine antiserum, as described in Experimental Procedures.

resed on polyacrylamide gels, and tyrosine-phosphorylated proteins were detected by immunoblotting with anti-phosphotyrosine antiserum. In cells treated with NGF, two tyrosine-phosphorylated proteins were detected that migrated with apparent $M_{r}$ values of 100 and 110 . These phosphoproteins were observed within $1 \mathrm{~min}$ of exposure to NGF and rapidly declined thereafter. EGF also stimulated the tyrosine phosphorylation of pp100 and pp110, although not as effectively as NGF. In insulin-treated PC12 cells, pp100 and pp110 were not detected, although a 185 kd tyrosine-phosphorylated protein, tentatively identified as insulin receptor substrate 1 (Sun et al., 1991), was found in anti-p85 immunoprecipitates within $1 \mathrm{~min}$ of exposure. The phosphorylation of this protein also declined thereafter, although it appeared to be more stable than the NGF-dependent phosphorylation of the 100 and $110 \mathrm{kd}$ proteins.

To evaluate the cell specificity of the NGF- and EGFdependent tyrosine phosphorylations of pp100 and $p p 110$, the effects of these growth factors were evaluated in other cell types expressing their respective receptors. 3T3-c-trk cells and NIH 3T3 cells transfected with the human EGF receptor (3T3/hEGFR) (Decker et al., 1990) were treated with NGF or EGF, and the lysates were precipitated with anti-p85 antiserum (Figure 5). The addition to 3T3-c-trk cells of $100 \mathrm{nMNGF}$ for $1 \mathrm{~min}$ 
A

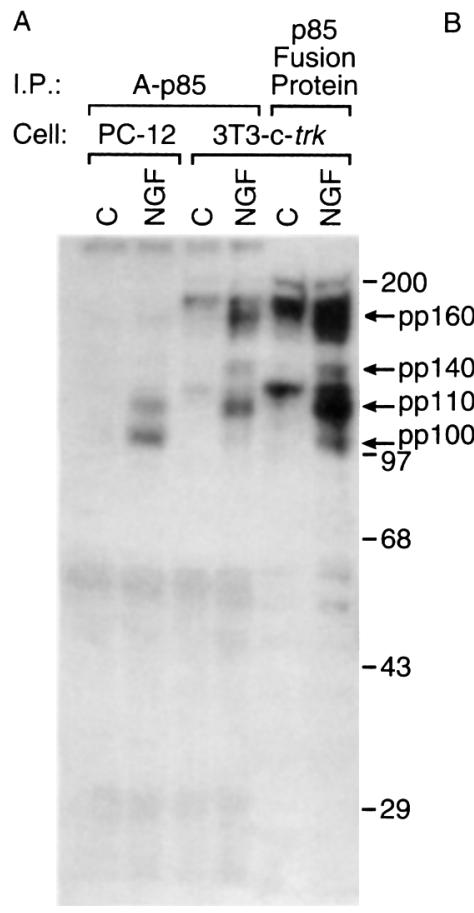

$\begin{array}{llllll}1 & 2 & 3 & 4 & 5 & 6\end{array}$

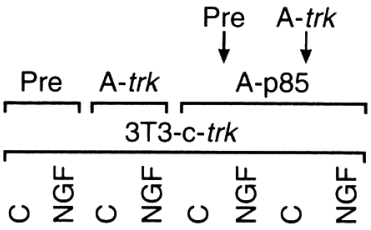

$-200$

$\leftarrow$ pp 160

$\leftarrow$ pp140

$\leftarrow$ pp110

$\leftarrow$ pp100

$-68$

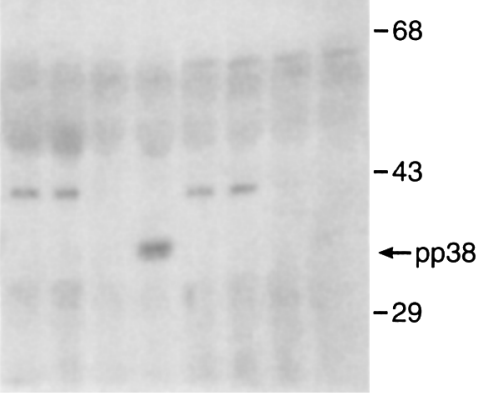

$\begin{array}{llllllll}1 & 2 & 3 & 4 & 5 & 6 & 7 & 8\end{array}$
C

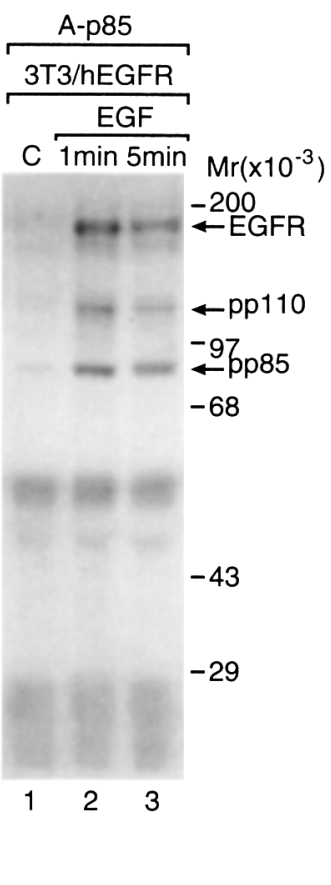

Figure 5. NGF Stimulates the Tyrosine Phosphorylation of Proteins in 3T3-c-trk Cells That Associate with the p85 SH2 Domain

PC12, 3T3-c-trk, and 3T3/hEGFR cells were grown in $150 \mathrm{~mm}$ dishes. NGF $(100 \mathrm{nM})$ or EGF (10 $\mathrm{nM})$ was directly added to the medium and incubated for the indicated times at $37^{\circ} \mathrm{C}$. (A) In lanes $1-4$, lysates were immunoprecipitated with anti-p85 antiserum and subject to SDS-PAGE, followed by immunoblotting with anti-phosphotyrosine antiserum. In lanes 5 and 6 , a GST-p85 SH2 fusion protein immobilized with glutathione-Sepharose beads was mixed with lysates from cells. Bound proteins were subject to SDS-PAGE followed by antiphosphotyrosine immunoblotting. (B) Lysates were immunoprecipitated with preimmune rabbit serum (lanes 1 and 2 ) or anti-trk antiserum (lanes 3 and 4). The resulting supernatants were subsequently precipitated with anti-p85 antiserum (lanes $5-8$ ) and subject to SDS-PAGE, followed by immunoblotting with anti-phosphotyrosine antiserum. (C) Lysates from 3T3/hEGFR cells were immunoprecipitated with anti-p85 antiserum and subject to SDS-PAGE, followed by immunoblotting with anti-phosphotyrosine antiserum.

induced the tyrosine phosphorylation of the two proteins ( $p p 100$ and $p p 110$ ) as well as additional proteins with molecular masses of $160 \mathrm{kd}$ and $140 \mathrm{kd}$ (Figure 5A). To explore whether the $140 \mathrm{kd}$ phosphoprotein identified in anti-p85 immunoprecipitates of 3T3-c-trk cells was the trk proto-oncogene, lysates from control and NGF-treated cells were preimmunoprecipitated with preimmune or anti-trk antisera, and the resulting supernatants were subsequently precipitated with anti-p85 antiserum (Figure 5B). Preimmunoprecipitation with anti-trk antiserum brought down the NGFdependent tyrosine phosphorylated pp140 ${ }^{\mathrm{c}-t r k}$ and its associated $38 \mathrm{kd}$ protein (Ohmichi et al., 1992c) (Figure 5B, lane 4), but did not clear the $140 \mathrm{kd}$ protein from the anti-p85 immunoprecipitates (Figure 5B, lane 8), suggesting that this $140 \mathrm{kd}$ band is not the trk protooncogene.

In contrast to PC12 cells, treatment of 3T3/hEGFR cells with EGF caused the coprecipitation of its tyrosine-phosphorylated receptor in the anti-p85 immunoprecipitate (Figure $5 \mathrm{C}$ ). These results suggested that the association of the EGFR with p85 occurs only in cells overexpressing this receptor, similar to what was observed for the association of this receptor with
PLC- $\gamma 1$ (Ohmichi et al., 1991b). Furthermore, the phosphorylation of p85 in response to NGF was not observed in either PC12 or 3T3-c-trk cells, despite the marked increase in PI kinase activity detected in the anti-phosphotyrosine immunoprecipitates. The presence of the p85 protein in anti-p85 immunoprecipitates from both cell types was confirmed by Western blotting with the same antiserum (Figure 6). Moreover, this antiserum can recognize phosphorylated p85, since the EGF-stimulated tyrosine phosphorylation of p85 was detected in immunoprecipitates from 3T3/hEGFR cells (Figure 5C). Interestingly, Western blotting of anti-trk immunoprecipitates from NGFtreated PC12 or 3T3-c-trk cells with anti-p85 revealed no evidence for p85. Additionally, blotting of anti-p85 immunoprecipitates from NGF-treated cells with antitrk antiserum revealed no evidence for pp140 ctrk (data not shown). However, the results in 3T3 cells overexpressing EGFR suggest that overexpression of the NGF receptor in cells may lead to NGF-dependent phosphorylation of $\mathrm{p} 85$ and direct association with its receptor.

The concentration dependence of the effect of NGF on the appearance of pp100/110 in the anti-p85 immu- 


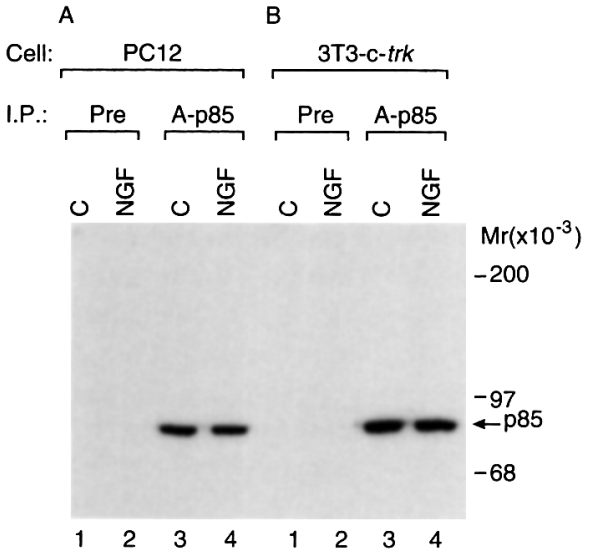

Figure 6. Detection of p85 in Immunoprecipitates by Western Blotting

PC12 (A) and 3T3-C-trk (B) cells were grown in $150 \mathrm{~mm}$ dishes. NGF $(100 \mathrm{nM})$ was directly added to the medium and incubated for $1 \mathrm{~min}$ at $37^{\circ} \mathrm{C}$, as described in Figure 4. Lysates were immunoprecipitated with preimmune rabbit serum (lanes 1 and 2) or anti-p85 antiserum (lanes 3 and 4) and subject to SDS-PAGE, followed by immunoblotting with anti-p85 antiserum, as described in Experimental Procedures.

noprecipitates was evaluated in PC12 cells (Figure 7). NGF caused a dose-dependent increase in the phosphorylation of these proteins, which was observed with as little as $1 \mathrm{nM}$ NGF and increased up to concentrations of $100 \mathrm{nM}$.

To explore further the nature of the association of these NGF- and EGF-dependent phosphoproteins with the p85 subunit of PI-3 kinase, we examined the effect of NGF on the binding of tyrosine-phosphorylated proteins to an immobilized fusion protein containing the amino-terminal $\mathrm{SH} 2$ domain of p85 (Figure 8). Cells were treated with the growth factors, and lysates were incubated with the immobilized fusion protein prior to SDS-polyacrylamide gel electrophoresis (PAGE) and immunoblotting with anti-phosphotyrosine antiserum. The addition to PC12 cells of NGF or EGF induced the association of both pp110 and pp100 with the $\mathrm{p} 85$ fusion protein, although neither receptor was detected in these precipitates. Moreover, the addition to 3T3-c-trk cells of NGF induced the association of pp110 and pp100 as well as pp140 and pp 160 (Figure $5 A$, lanes 5 and 6 ). In contrast, treatment of 3T3/hEGFR cells with EGF caused the association of its tyrosine-phosphorylated receptor with the fusion protein, as well as additional proteins, including pp110. Additionally, treatment of Swiss 3T3 cells with PDGF also stimulated the association of its tyrosine-phosphorylated receptor (molecular mass, 190 $\mathrm{kd}$ ) with the $\mathrm{SH} 2$ domain fusion protein. In insulintreated PC12 and HIRc cells (overexpressing the human insulin receptor), both the $\boldsymbol{\beta}$ subunit of the insulin receptor (molecular mass, $95 \mathrm{kd}$ ) and a protein tentatively identified as insulin receptor substrate 1 (molecular mass, $185 \mathrm{kd}$ ) were detected, as well as

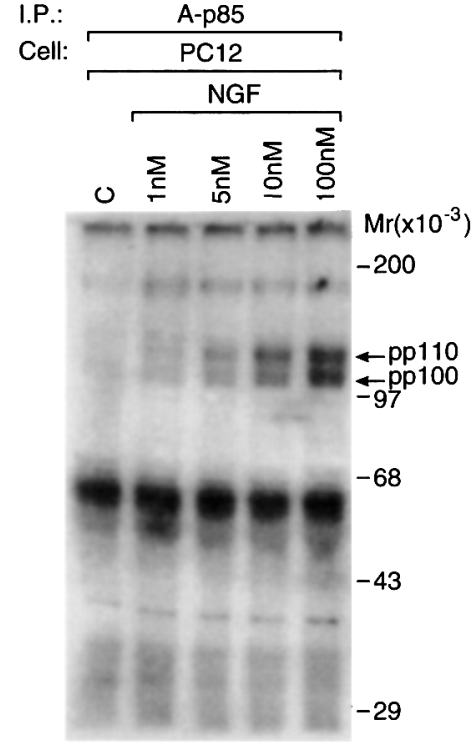

Figure 7. The Dose Dependence of NGF-Induced Tyrosine Phosphorylation of pp100 and pp110 in PC12 Cells

PC12 cells were treated with the indicated concentrations of NGF for $1 \mathrm{~min}$ at $37^{\circ} \mathrm{C}$. Lysates were immunoprecipitated with anti-p85 antiserum and subject to SDS-PAGE, followed by immunoblotting with anti-phosphotyrosine antiserum.

the $110 \mathrm{kd}$ protein, although the $100 \mathrm{kd} \mathrm{NGF-} \mathrm{and}$ EGF-sensitive protein was not found.

\section{Discussion}

Like many other growth factors with tyrosine kinase receptors, NGF rapidly stimulates the activity of PI-3

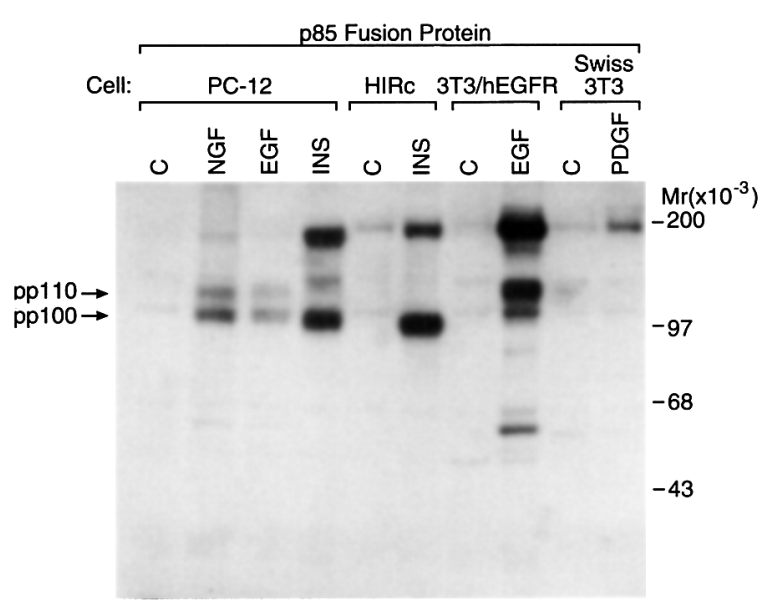

Figure 8. NGF, EGF, and Insulin Induce the Association of Tyrosine-Phosphorylated Proteins with the p85 SH2 Domain

PC12, HIRc, 3T3/hEGFR, and Swiss 3T3 cells were grown in 150 $\mathrm{mm}$ dishes. NGF (100 nM), EGF (10 nM), insulin (100 nM), or PDGF $(10 \mathrm{nM})$ was directly added to the medium and incubated for $1 \mathrm{~min}$ at $37^{\circ} \mathrm{C}$. Lysates were incubated with a GST-p85 fusion protein immobilized with glutathione-Sepharose beads. The association of tyrosine-phosphorylated proteins with the fusion protein was evaluated as described in Figure 5. 
kinase. Although the role of the novel lipid products of this enzyme, as well as the mechanism of activation, remains poorly understood, there is little doubt that cellular tyrosine phosphorylation plays an important role (Kaplan et al., 1987; Auger et al., 1989; Coughlin et al., 1989; Bjorge et al., 1990; Endermann et al., 1990; Kazlauskas and Cooper, 1990; Hu et al., 1992). NGF-, EGF-, and insulin-stimulated PI-3 kinase activities were detected in anti-phosphotyrosine immunoprecipitates, suggesting that the enzyme is itself phosphorylated or can associate with one or more growth factordependent tyrosine-phosphorylated proteins. However, in the case of NGF, there is no evidence that the $\mathrm{Pl}-3$ kinase itself can directly associate with the tyrosine-phosphorylated NGF receptor. Although it is possible that the anti-trk antibody employed in these studies blocks PI-3 kinase activity or association with the receptor, this antiserum did not precipitate $\mathrm{PI}-3$ kinase activity. Moreover, immunoblotting of anti-trk immunoprecipitates from NGF-treated cells with antip85 antiserum, or blotting of anti-p85 immunoprecipitates with anti-trk antiserum, revealed no evidence for the association of $\mathrm{p} 85$. In addition, the $\mathrm{pp} 140^{\mathrm{c}-\mathrm{trk}}$ protein was not detected in anti-p85 or p85 SH2 fusion protein precipitates from NGF-treated cells, in contrast to the identification of the tyrosine-phosphorylated receptor in anti-PLC- $\gamma 1$ or PLC- $\gamma 1 \mathrm{SH} 2$ fusion protein precipitates (Ohmichi et al., 1991b). The lack of NGF receptor association with p85 is not surprising, since the tyrosine kinase domain of trk lacks the nucleotide consensus sequence (EYMXM) thought to be required for $\mathrm{p} 85$ binding, although it does have a region of some similarity (FEYMRHGD) around Tyr-595. Additionally, there is also no evidence that p85 itself undergoes phosphorylation on tyrosine in response to NGF, since an $85 \mathrm{kd}$ tyrosine-phosphorylated band was not detected in anti-p85 immunoprecipitates in response to the growth factors, despite the presence of this protein, as verified by immunoblotting.

Interestingly, NGF did cause the tyrosine phosphorylation of two proteins at $100 \mathrm{kd}$ and $110 \mathrm{kd}$, detected by their coimmunoprecipitation with anti-p85 antiserum or association with the $\mathrm{p} 85 \mathrm{SH} 2$ fusion protein. The appearance of these phosphoproteins temporally correlated with stimulation of PI-3 kinase activity, although there were discrepancies regarding the extent of phosphorylation observed with NC.F and EGF and their relative activations of the enzyme. It is important to note, however, that our ability to detect phosphorylation depends upon association of these proteins with the p85 protein, so the extent of phosphorylation observed here may be misleading. However, the $\mathrm{SH} 2$ association of pp100 and pp110 was specific for $p 85$, since these bands were not detected in anti-PLC- $\gamma 1$ or anti-GTPase activating protein (of ras) immunoprecipitates and were not associated with immobilized fusion proteins containing $\mathrm{SH} 2$ domains of these proteins (Ohmichi et al., 1991b).

It is possible that the $110 \mathrm{kd}$ protein detected in these precipitates is the catalytic subunit of $\mathrm{Pl}-3$ kinase
(Carpenter et al., 1990), although there is no direct evidence to support this spcculation. Moreover, another interesting possibility is that pp100, which is phosphorylated in response to both NGF and EGF, may represent a specific $\mathrm{p} 85$-binding protein that mediates activation of $\mathrm{Pl}-3$ kinase by these factors. In this regard, pp100 may be analogous to the pp185 insulin receptor substrate 1 , which contains up to ten $\mathrm{p} 85$ binding motifs and is likely to mediate the insulindependent activation of $\mathrm{Pl}-3$ kinase (Endermann et al., 1990; Ruderman et al., 1990).

The stimulation of PI-3 kinase activity represents another early cellular response that NGF shares with a number of mitogenic factors, notably, EGF and insulin (Saltiel and Decker, 1991). These factors produce similar, but not identical tyrosine phosphorylations (Miyasaka et al., 1991; Ohmichi et al., 1992a, 1992c) and similarly stimulate the serine/threonine phosphorylation and activation of microtubule-associated protein kinase (Miyasaka et al., 1990), S6 kinase (Matsuda and Guroff, 1987), protein kinase C (Hama et al., 1986; Heasley and Johnson, 1989a), and raf-1 kinase (Ohmichi et al., 1992b). Despite these numerous similarities in early signaling events, the downstream cellular actions of these factors in PC12 cells are quite different. Most notable is the distinction between the differentiative activity of NGF and the mitogenic activity of EGF. One possible clue for solving this apparent paradox may lie in the differential associations of these tyrosine kinase receptors with proteins containing $\mathrm{SH} 2$ domains. Studies in PC12 and 3T3-c-trk cells indicate that the NGF receptor associates with PLC- $\gamma 1$ (Ohmichi et al., 1991b), does not associate with GTPase activating protein of ras (Ohmichi et al., 1991b), and may activate Pl-3 kinase via an indirect mechanism, whereas both the EGF and insulin receptors exhibit quite different patterns of $\mathrm{SH} 2$ binding in these cells (Ohmichi et al., 1992c). Although the downstream events that allow cells to distinguish growth and differentiative signals remain a mystery, it is likely that the close examination of divergent signaling emerging from these receptors may yield much information.

\section{Experimental Procedures}

\section{Materials}

[ $\gamma$-32P]ATP (300 Ci/mol) was from New England Nuclear (Bannockburn, IL). ${ }^{125}$ l-labeled protein A ( $30 \mathrm{mCi} / \mathrm{mg}$ ) was from Amersham (Arlington Heights, IL). NGF 2.5S was from Bioproducts for Science (Indianapolis, IL). Receptor grade EGF was from Collaborative Research (Lexington, MA). Recombinant human PDGF- $\beta \beta$ homodimer was from Bachem (Torrance, CA). Insulin was from Eli Lilly (Indianapolis, IN). Silica gel thin-layer chromatography plates were from EM Separations (Cibbstown, NJ). Anti-phosphotyrosine monoclonal antiserum and anti-p85 polyclonal antiserum were from Upstate Biotechnology (Lake Placid, NY). All other reagents were purchased from Sigma (St. Louis, $\mathrm{MO}$ ) and were the highest quality available. Anti-trk antiserum (Ohmichi et al., 1991a, 1991b) was developed as described previously. The pGEX plasmid expressing the amino-terminal SH2 domain of $\mathrm{p} 85$ in a GST fusion protein was the generous gift of Drs. B. Margolis and $\mathrm{J}$. Schlessinger and contained the amino-terminal $\mathrm{SH}_{2} \mathrm{do}-$ main of the p85 subunit (Hu et al., 1992). 


\section{Cell Culture}

NIH 3T3 cells were transfected with the plasmid pCO12-trk containing the full-length human trk cDNA (generous gift of Dr. Luis Parada) (3r3-c-trk) (Ohmichi et al., 1992b) in the pCO12 vector as described previously (Velu et al., 1987). NIH 3T3 cells were transfected with the normal human EGFR (3T3/hEGFR) (Decker et al., 1990). PC12 cells, 3T3-c-trk cells, NIH/hEGFR cells, and Swiss-3T3 cells were grown in Dulbecco's modified Eagle's medium containing $4500 \mathrm{mg}$ per liter of D-glucose and $10 \%$ fetal bovine serum. Rat fibroblasts expressing 300,000 normal human insulin receptors $(H I R c)$, which were the generous gift of $\mathrm{Dr}$. Donald A. McClain (Maegawa et al., 1988; McClain et al., 1988), were grown in Dulbecco's modified Eagle's/F12 medium with $10 \%$ fetal bovine serum and $100 \mathrm{nM}$ methotrexate.

\section{Assay of PI-3 Kinase Activity}

Cells were grown in $150 \mathrm{~mm}$ dishes. Growth factors were directly added to the medium and incubated for the indicated times at $37^{\circ} \mathrm{C}$. After hormonal treatment, the medium was removed, and cells were washed twice with $12 \mathrm{ml}$ of ice-cold phosphatebuffered saline before the addition of $1 \mathrm{ml}$ of Nonidet $\mathrm{P}-40$ buffer (20 mM Tris [pH 7.5], $150 \mathrm{mM} \mathrm{NaCl}, 1 \%$ Nonidet P-40, 5 mM EDTA, $100 \mu \mathrm{M}$ sodium orthovanadate, $10 \mu \mathrm{g} / \mathrm{ml}$ aprotinin, $10 \mu \mathrm{g} / \mathrm{ml}$ leupeptin, and $1 \mathrm{mM}$ phenylmethylsulfonyl fluoride). Lysates were centrifuged at $10,000 \times \mathrm{g}$ for $10 \mathrm{~min}$. The resulting supernatants were incubated for $1 \mathrm{hr}$ with the indicated antisera. Following the incubation, protein A-Sepharose beads were added for 30 mim with mixing, and immune complexes bound to the beads were washed three times with Nonidet $P-40$ buffer, once with phosphate-buffered saline, once with $0.5 \mathrm{M} \mathrm{LiCl} / 0.1 \mathrm{M}$ Tris $(\mathrm{pH}$ 7.5), once with distilled water, and once with $0.1 \mathrm{M} \mathrm{NaCl} / 0.1 \mathrm{mM}$ EDTA $10 \mathrm{mM}$ Tris (pH 7.5). The PI-3 kinase assay was performed by adding to the immunoprecipitate $50 \mu \mathrm{l}$ of $\mathrm{PI}$ kinase buffer (10 $\mathrm{mM}$ Tris [pH 7.5], $0.2 \mathrm{mM}$ EGTA, $100 \mathrm{mM} \mathrm{NaCl}), 0.5 \mathrm{mg} / \mathrm{ml} \mathrm{Pl}, 20$ $\mathrm{mM} \mathrm{MgCl}$, and $10 \mu \mathrm{M}\left[\gamma^{-32}{ }^{32}\right] \mathrm{ATP}(10 \mu \mathrm{Ci}$ per assay), followed by the addition of $100 \mu$ l of chloroform, methanol, $\mathrm{HCl}$ (100:200:2), and then $100 \mu \mathrm{l}$ of chloroform and $100 \mu \mathrm{l}$ of water were added. The resulting organic was dried, resuspended in $50 \mu \mathrm{l}$ of chloroform, methanol (1:1), and spotted on a silica gel thin-layer chromatography plate that was developed in chloroform, methanol, water, ammonium hydroxide (43:38:7:5). ${ }^{32} \mathrm{P}$-labeled PI-3 phosphate was visualized by autoradiography and compared with an iodine-stained standard.

\section{Anti-Phosphotyrosine Immunoblots}

Cells were grown in $150 \mathrm{~mm}$ dishes. Before hormonal treatment, the medium was replaced with serum-free medium and incubated for $1 \mathrm{hr}$. Unless otherwise indicated, $100 \mathrm{nM}$ NGF, $10 \mathrm{nM}$ EGF, $10 \mathrm{nM}$ PDGF, or $100 \mathrm{nM}$ insulin was directly added to the medium and incubated for $1 \mathrm{~min}$ at $37^{\circ} \mathrm{C}$. After hormonal treatment, the medium was removed, and cells were washed twice with $12 \mathrm{ml}$ of ice-cold phosphate-buffered saline before the addition of $1 \mathrm{ml}$ of HNTC buffer (50 mM HEPES [pH 7.5], $150 \mathrm{mM}$ $\mathrm{NaCl}, 10 \%$ glycerol, $1 \%$ Triton X-100, $1.5 \mathrm{mM} \mathrm{MgCl}_{2}, 1 \mathrm{mM}$ EDTA, $10 \mu \mathrm{M}$ sodium pyrophosphate, $200 \mu \mathrm{M}$ sodium orthovanadate, $100 \mathrm{mM} \mathrm{NaF}, 30 \mathrm{mM}$ p-nitrophosphate, $10 \mu \mathrm{g} / \mathrm{ml}$ aprotinin, 10 $\mu \mathrm{g} / \mathrm{m}$ l leupeptin, and $1 \mathrm{mM}$ phenylmethyl sulfonyl fluoride) (Margolis et al., 1990a). Lysates were centrifuged at $10,000 \times \mathrm{g}$ for 10 min. Supernatants were incubated for $1 \mathrm{hr}$ with the indicated antisera. Following the incubation, protein $\mathrm{A}$-Sepharose beads were added for $30 \mathrm{~min}$ with mixing, and immune complexes bound to the beads were washed three times with $1 \mathrm{ml}$ of HNTG buffer. Immune complexes were solubilized in $25 \mu \mathrm{l}$ of Laemmli sample buffer (Laemmli et al., 1970) and electrophoresed on $8 \%$ SDS polyacryamide gels. Transfer to nitrocellulose paper, immunoblotting with anti-phosphotyrosine antiserum, and washing were performed as described (Decker et al., 1990). For blotting of tyrosine-phosphorylated proteins binding to the bacterially expressed SH domain of $p 85$, supernatants were incubated for $90 \mathrm{~min}$ with glutathione-Sepharose beads, to which the GSTp85 fusion protein had been bound. The beads were washed three times with $1 \mathrm{ml}$ of HNTG buffer, and samples were resolved on $8 \%$ SDS gels.

\section{Acknowledgments}

This work was supported by grants DK33804 (A. R. S.) and CA37754 (S. J. D.). We thank Cathy Mazur for excellent technical assistance and Dr. Long Pang for development of anti-trk antiserum.

The costs of publication of this article were defrayed in part by the payment of page charges. This article must therefore be hereby marked "advertisement" in accordance with 18 USC Section 1734 solely to indicate this fact.

Received May 11, 1992; revised July 6, 1992.

\section{References}

Aletta, T. M., Lewis, S. A., Cowan, N. J., and Greene, L. A. (1988). Nerve growth factor regulates both the phosphorylation and steady-state levels of microtubule-associated protein 1.2 (MAP1.2). J. Cell Biol. 106, 1573-1581.

Anderson, D., Koch, C. A., Grey, L., Ellis, C., Moran, M. F., and Pawson, T. (1990). Binding of SH2 domains of phospholipase $\mathrm{C}-\gamma 1, \mathrm{GAP}$, and Src to activated growth factor receptors. Science 250, 979-982.

Auger, K. R., Serunian, L. A., Soltoff, S. P., Libby, P., and Cantley, L. C. (1989). PDGF-dependent tyrosine phosphorylation stimulates production of novel polyphosphoinositides in intact cells. Cell 57, 167-175.

Bjorge, J. D., Chan, T., Antczak, M., Kung, H., and Fugita, D. J. (1990). Activated type 1 phosphatidylinositol kinase is associated with the epidermal growth factor (EGF) receptor following EGF stimulation. Proc. Natl. Acad. Sci. USA 87, 3816-3820.

Cantley, L. C., Auger, K. R., Carpenter, C., Duckworth, B., Graziani, A., Kapeller, R., and Soltoff, S. (1991). Oncogenes and signal transduction. Cell 64, 281-302.

Carpenter, C. L., Duckworth, B. C., Auger, K. R., Cohen, B., Schaffhausen, B. S., and Cantley, L. C. (1990). Purification and characterization of phosphoinositide 3-kinase from rat liver. J. Biol. Chem. 265, 19704-19711.

Coughlin, S. R., Escobedo, J. A., and Williams, L. T. (1989). Role of phosphatidylinositol kinase in PDGF receptor signal transduction. Science 243, 1191-1194.

Decker, S. J., Ellis, C., Pawson, T., and Velu, T. (1990). Effects of substitution of threonine 654 of the epidermal growth factor receptor on epidermal growth factor-mediated activation of phospholipase C. J. Biol. Chem. 265, 7009-7015.

Ellis, C., Moran, M., McCormick, F., and Pawson, T. (1990). Phosphorylation of GAP and GAP-associated proteins by transforming and mitogenic tyrosine kinases. Science 343, 377-381. Endermann, G., Yonezawa, K., and Roth, R. A. (1990). Phosphatidylinositol kinase or an associated protein is a substrate for the insulin receptor tyrosine kinase. J. Biol. Chem. 265, 396-400.

Fsrohedo, J. A., Kaplan, D. R., Kavanaugh, W. M., Turck, C. W., and Williams, L. T. (1991a). A phosphatidylinositol-3 kinase binds to platelet-derived growth factor receptors through a specific receptor sequence containing phosphotyrosine. Mol. Cell. Biol. $11,1125-1132$.

Escobedo, J. A., Navankasattusas, S., Kavanaugh, W. M., Milfay, D., Fried, V. A., and Williams, L. T. (1991b). cDNA cluning of a novel $85 \mathrm{kd}$ protein that has $\mathrm{SH} 2$ domains and regulates binding of PI3-kinase to the PDGF $\beta$-receptor. Cell 65, 75-82.

Fukui, Y., Saltiel, A. R., and Hanafusa, H. (1991). Phosphatidylinositol-3 kinase is activated in v-src, $v$-yes, and $v$-fps transformed chicken embryo fibroblasts. Oncogene 6, 407-411.

Halegoua, S., and Patrick, J. (1980). Nerve growth factor mediates phosphorylation of specific proteins. Cell 22, 571-581.

Hama, T., Huang, K. P., and Guroff, G. (1986). Protein kinase C as a component of a nerve growth factor-sensitive phosphorylation system in PC-12 cells. Proc. Natl. Acad. Sci. USA 83, 2353-2357. Heasley, L. E., and Johnson, C. L. (1989a). Regulation of protein kinase $\mathrm{C}$ by nerve growth factor, epidermal growth factor, and 
phorbol esters in PC-12 pheochromocytoma cells. J. Biol. Chem. 264, 8646-8652.

Heasley, L. E., and Johnson, G. L. (1989b). Detection of nerve growth factor and epidermal growth factor regulated protein kinases in PC-12 cells with synthetic peptide substrates. Mol. Pharmacol. 35, 331-338.

Hu, P., Margolis, B., Skolnik, E. Y., Lammers, R., Ulirich, A., and Schlessinger, J. (1992). Interaction of phosphatidylinositol 3-kinase-associated p85 with EGF and PDGF receptors. Mol. Cell. Biol. 12, 981-990.

Kaplan, D. R., Whitman, M., Schaffhausen, B., Pallas, D. C. White, M., Cantley, L., and Roberts, T. M. (1987). Common elements in growth factor stimulation and oncogenic transformation: $85 \mathrm{kd}$ phosphoprotein and phosphatidylinositol kinase activity. Cell 50, 1021-1029.

Kaplan, D. R., Morrison, D. K., Wong, G., McCormick, F., and Williams, L. T. (1990). PDGF $\beta$-receptor stimulates tyrosine phosphorylation of GAP and association of GAP with a signaling complex. Cell 61, 125-133.

Kaplan, D. R., Martin-Zanca, D., and Parada, L. F. (1991a). Tyrosine-phosphorylation and tyrosine kinase activity of trk protooncogene product induced by NGF. Nature 350, 158-160.

Kaplan, D. R., Hempstead, B. L., Martin-Zanca, D., Chao, M. V., and Parada, L. F. (1991b). The trk proto-oncogene product: a signal transducing receptor for nerve growth factor. Science 252 , 552-558.

Kazlauskas, A., and Cooper, J. A. (1989). Autophosphorylation of the PDGF receptor in the kinase insert region regulates interactions with cell proteins. Cell 58, 1121-1133.

Kazlauskas, A., and Cooper, I. A. (1990). Phosphorylation of the PDGF receptor $\beta$ subunit creates a tight binding site for phosphatidylinositol 3 kinase. EMBO J. 9, 3279-3286.

Kazlauskas, A., Ellis, C., Pawson, T., and Cooper, J. A. (1990). Binding of GAP to activated PDGF receptors. Science 247, 15781581.

Kim, U. H., Fink, D., Jr., Kim, H. S., Park, D. I., Contreras, M. L. Guroff, G., and Rhee, S. G. (1991). Nerve growth factor stimulates phosphorylation of phospholipase $\mathrm{C}-\gamma$ in $\mathrm{PC} 12$ cells. J. Biol. Chem. 266, 1359-1362.

Klein, R., Jing, S., Nanduri, K. V., O'Rourke, E., and Barbacid M. (1991). The trk proto-oncogene encodes a receptor for nerve growth factor. Cell 65, 189-197.

Kumjian, D. A., Wahl, M. I., Rhee, S. G., and Daniel, T. O. (1989). Platelet-derived growth factor (PDGF) binding promotes physical association of PDGF receptor with phospholipase C. Proc. Natl. Acad. Sci. USA 86, 8232-8236.

Laemmli, U. K. (1970). Cleavage of structural proteins during the assembly of the head of bacteriophage T4. Nature 227, 680-685. Landreth, G. E., and Rieser, G. D. (1985). Nerve growth factorand epidermal growth factor-stimulated phosphorylation of a PC12 cytoskeletally associated protein in situ. J. Cell Biol. 100, 677-683.

Lee, K. Y., Seeley, D. J., Muller, T. H., Helmer-Matyjek, E., Sabban, E., Goldstern, M., and Greene, L. A. (1985). Regulation of tyrosine hydroxylase phosphorylation of $\mathrm{PC}-12$ pheochromocytoma cells by elevated $\mathrm{K}^{+}$and nerve growth factor. Mol. Pharmacol. 28, 220228.

Maegawa, H., McClain, D. A., Freidengerg, G., Olefsky, J. M. Napier, M., Lipari, T., Dull, T. J., Lee, J., and Ullrich, A. (1988) Properties of a human insulin receptor with a $\mathrm{COOH}$-terminal truncation. J. Biol. Chem. 263, 8912-8917.

Margolis, B., Rhee, S. G., Felder, S., Mervic, M., Lyall, R., Levitzki, A., Ulirich, A., Zilberstein, A., and Schlessinger, J. (1989). EGF induces tyrosine phosphorylation of phospholipase C-Il: a potential mechanism for $\mathrm{EGF}$ receptor signaling. Cell $57,1101-1107$. Margolis, B., Bellot, F., Honegger, A. M., Ulirich, A., Schlessinger, I., and Zilberstein, A. (1990a). Tyrosine kinase activity is essentia for the association of phospholipase $\mathrm{C}-\gamma$ with the epidermal growth factor. Mol. Cell. Biol. 10, 435-441.
Margolis, B., Li, N., Koch, A., Mohammadi, M., Hurwitz, D. R. Zilbertein, A., Ullrich, A., Pawson, T., and Srhlessinger, J. (1990b) The tyrosine phosphorylated carboxyterminus of the EGF receptor is a binding site for GAP and PLC- $\gamma$. EMBO J. 9, 4375-4380. Matsuda, Y., and Guroff, G. (1987). Purification and mechanism of activation of a nerve growth factor-sensitive $\mathrm{S} 6$ kinase from PC-12 cells. J. Biol. Chem. 262, 2832-2844.

McClain, D. A., Maegawa, H., Levy, J., Hueckstead, T., Dull, T. J. Lee, J., Ullrich, A., and Olefsky, J. M. (1988). Properties of a human insulin receptor with a $\mathrm{COOH}$-terminal truncation. J. Biol. Chem 263, 8904-8911.

Meisenhelder, J., Suh, P.-G., Rhee, S. G., and Hunter, T. (1989). Phospholipase C- $\gamma$ is a substrate for the PDC.F and ECF receptor protein-tyrosine kinases in vivo and in vitro. Cell 57, 1109-1122. Miyasaka, T., Chao, M. V., Sherline, P., and Saltiel, A. R. (1990). Nerve growth factor stimulates a protein kinase in PC-12 cells that phosphorylates microtubule-associated protein-2. J. Biol Chem. 265, 4730-4747.

Miyasaka, T., Sternberg, D. W., Miyasaka, J., Sherline, P., and Saltiel, A. R. (1991). Nerve growth factor stimulates protein tyrosine phosphorylation in PC- 12 pheochromocytoma cells. Proc Natl. Acad. Sci. USA 88, 2653-2657.

Molly, C. J., Bottaro, D. P., Fleming, T. P., Marshall, M. S., Gibbs, I. B., and Aaronson, S. A. (1988). PDGF induction of tyrosine phosphorylation of GTPase activating protein. Nature $342,711-$ 714.

Moran, M. F., Koch, C. A., Anderson, D., Ellis, C., England, L., Martin, G. S., and Pawson, T. (1990). Src homology region 2 domains direct protein-protein interactions in signal transduction. Proc. Natl. Acad. Sci. USA 87, 8622-8626.

Nakanishi, N., and Guroff, G. (1985). Nerve growth factorinduced increase in the cell-free phosphorylation of a nuclear protein in PC12 cells. J. Biol. Chem. 260, 7791-7799.

Ohmichi, M. Decker, S. I. Pang, L., and Saltiel, A. R. (1991a). Phospholipase C- $\gamma 1$ directly associates with the $\mathrm{p} 70$ trk oncogene product through its src homology domains. J. Biol. Chem. 266, 14858-14861.

Ohmichi, M., Decker, S. J., Pang, L., and Saltiel, A. R. (1991b). Nerve growth factor binds to the $140 \mathrm{kd}$ trk proto-oncogene product and stimulates its association with the src homology domain of phospholipase C- $\gamma 1$. Biochem. Biophys. Res. Commun. 179, 217-223.

Ohmichi, M., Decker, S. I., Pang, L., and Saltiel, A. R. (1992a) Inhibition of the cellular actions of nerve growth factor by staurosporine and $\mathrm{K} 252 \mathrm{~A}$ results from the attenuation of the activity of the trk tyrosine kinase. Biochemistry 31, 4034-4039.

Ohmichi, M., Pang, L., Decker, S. J., and Saltiel, A. R. (1992b). Nerve growth factor stimulates the activities of the raf-1 and the mitogen-activated protein kinases via the trk protooncogene. J. Biol. Chem. 267, 14604-14610.

Ohmichi, M. Decker, S. J., and Saltiel, A. R. (1992C). Nerve growth factor stimulates the tyrosine phosphorylation of a $38 \mathrm{kD}$ protein that specifically associates with the src homology domain of phospholipase C- $\gamma 1$. J. Biol. Chem., in press.

Otsu, M., Hiles, I., Gout, I., Fry, M. J., Ruiz-Larrea, F., Panayotou, G., Thompson, A., Dhand, R., Hsuan, J., Totty, N., Smith, A. D., Morgan, S. J., Courtneidge, S. A., Parker, P. J., and Waterfield, M. D. (1991). Characterization of two $85 \mathrm{kd}$ proteins that associate with receptor tyrosine kinases, middle T-pp $60^{c-s i c}$ complexes, and PI3-kinase. Cell 65, 91-104.

Rawland, E. A., Muller, T. H., Goldstein, M., and Greene, L. A. (1987). Cell-free detection and characterization of a novel nerve growth factor-activated protein kinase in PC-12 cells. J. Biol. Chem. 262, 7504-7513.

Reedijk, M., Liu, X., and Pawson, T. (1990). Interactions of phosphatidylinositol kinase, GTPase-activating (GAP), and GAP-associated proteins with the colony-stimulating factor 1 receptor. Mol. Cell. Biol. 10, 5601-5608.

Ruderman, N. B., Kapeller, R., White, M. F., and Cantley, L. C. 
(1990). Activation of phosphatidylinositol 3-kinase by insulin. Proc. Natl. Acad. Sci. USA 87, 1411-1415.

Saltiel, A. R., and Decker, S. J. (1991). Diversity in cellular signaling $\mathrm{f} c \mathrm{r}$ nerve growth factor and insulin: variations on a common theme. Mol. Cell. Endocrinol. 81, C197-C202.

Shurtleff, S. A., Downing, J. R., Rock, C. O., Hawkins, S. A., Roussel, M. F., and Sherr, C. J. (1990). Structural features of the colonystimulating factor 1 receptor that affect its association with phosphatidylinositol 3-kinase. EMBO J. 9, 2415-2421.

Skolnik, E. Y., Margolis, B., Mołammadi, M., Lowenstein, E., Fischer, R., Drepps, A., Ullrich, A., and Schlessinger, J. (1991). C oning of $\mathrm{Pl} 3$ kinase-associated p85 utilizing a novel method for expression/cloning of target proteins for receptor tyrosine kinases. Cell 65, 83-90.

Sun, X. J., Rothenberg, P., Kahn, C. R., Backer, J. M., Araki, E., Wilden, P. A., Cahill, D. A., Goldstein, B. J., and White, M. F. (1991). Structure of the insulin receptor substrate IRS-1 defines a unique signal transduction protein. Nature $352,73-77$.

Trahey, M., Wong, G., Halenbeck, R., Rubinfeld, B., Martin, G. A., Ladner, M., Long, C. M., Crosier, W. J., Watt, K., Koths, K., and N cCormick, F. (1988). Molecular cloning of two types of GAP complementary DNA from human placenta. Science 242, 16971700.

Varticovski, L., Druker, B., Morrison, D., Cantley, L., and Roberts, T. (1989). The colony stimulating factor-1 receptor associates with and activates phosphatidylinositol-3 kinase. Nature 342, 699-702. Velu, T. J., Beguinot, L., Vass, W. C., Willingham, M. C., Merlinto, G. T., Pastan, I., and Lowy, D. R. (1987). Epidermal growth factordependent transformation by a human EGF receptor protoo: cogene. Science 238, 1408-1410.

Vulliet, P. R., Hall, F. L., Mitchell, J. P., and Hardie, D. G. (1989), Icientification of a novel proline-directed serine/threonine protein kinase in rat pheochromocytoma. J. Biol. Chem. 264, 1629216298.

W'ahI, M. I., Daniel, T.O., and Carpenter, G. (1988). Antiphosphoty rosine recovery of phospholipase $C$ activity after EGF treatment o: A-431 cells. Science 241, 968-970.

Wahl, M. I., Nishibe, S., Suh, P. G., Rhee, S. G., and Carpenter, C. (1989a). Epidermal growth factor stimulates tyrosine phosphorylation of phospholipase C-2 independently of receptor internalization and extracellular calcium. Proc. Natl. Acad. Sci. USA 86, 1568-1572.

Wahl, M. I., Olashaw, N. E., Nishibe, S., Rhee, S. G., Pledger, W. J., and Carpenter, G. (1989b). Platelet-derived growth factor induces rapid and sustained tyrosine phosphorylation of phospholipase $\mathrm{C}-\gamma$ in quiescent BALB/c3T3 cells. Mol. Cell. Biol. 9, 2934-2943.

Weskamp, G., and Reichardt, L. F. (1991). Evidence that biological activity of NGF is mediated through a novel subclass of high a finity receptors. Neuron 6, 649-663.

Whitman, M., Kaplan, D., Roberts, T., and Cantley, L. (1987). Evidence for two distinct phosphatidylinositol kinases in fibroblasts. Biochem. J. 247, 165-174. 